\title{
KARAKTERISTIK CERPEN-CERPEN CYBER
}

\author{
Kusmarwanti \\ FBS Universitas Negeri Yogyakarta \\ email kusmarwanti@gmail.com
}

\begin{abstract}
This research study aims to describe the characteristics of the site that includes short stories cyber, the fact of short stories cyber, namely plot, character, and setting, and the characteristics of the reader and the author of short stories cyber. The research subjects were short stories cyber in www.kolomkita.com dan www.kemudian.com that published in April 2008. The data collected through data cards and analyzed by categorizing them in accordance with the predetermined categories. The research finding show that the site that contains short stories cyber determined by its organizer, both vision and personal as admin. Second, sites that contain short stories have hardly any cyber script selection process so that cyber short story has some weakness on the resolution of the story, the cultivation of the conflict, climax, character, and setting. A lot of short stories cyber are unfinished and very short. The short stories writer and reader cyber is a community that found a path from them, by them, and for them.
\end{abstract}

Key word: short story cyber, the site, fact of story, writer, reader

\section{PENDAHULUAN}

Era digital membawa kemungkinan baru dalam perkembangan sastra Indonesia. Blog dan website di internet untuk publikasi karya bermunculan. Blog dan website itu merupakan milik pribadi (misalnya Gonawan Mohamad, Joko Pinurbo, dan sebagainya) atau milik komunitas sastra (misalnya www. cybersastra.net, www.kolomkita.com, www.kemudian.com, dan sebagainya).

Keberadaan berbagai karya di internet ini memunculkan satu perkembangan genre baru sastra yang dikenal sebagai sastra cyber. Di antara berbagai bentuk karya tersebut, cerpen merupakan bentuk yang cukup menonjol dan banyak diminati. Dengan alasan inilah penelitian ini mengangkat permasalahan yang berkaitan dengan cerpen cyber.

Munculnya sastra cyber di Indonesia ditanggapi secara beragam. Pihak yang mengapresiasi secara positif berargumen bahwa melalui media cyber, keberadaan dan perkembangan sastra dapat diakses oleh kalangan yang lebih luas, tidak hanya masyarakat Indonesia tetapi juga masyarakat seluruh dunia. Dengan demikian, sastra menjadi milik semua orang karena mereka bisa mencintai dan mengapresiasinya (Situmorang, 2004:ix-x). Sementara itu, tanggapan negatif muncul terkait dengan kualitas karya karena tidak ada proses seleksi dari pengelola sehingga semua karya, yang bagus dan yang tidak, bisa muncul di situs tersebut. Secara kasar bahkan Herfanda (2004:71) menyebut situs ini sebagai "tong sampah" karena memuat karya-karya yang tidak dimuat di media cetak.

Selain itu, Herfanda juga mempertanyakan keberadaan sastra cyber ini mengingat situs ini juga dimanfaatkan sebagai media alternatif sosialisasi karya sastra karena ia menayangulangkan karya-karya yang pernah dimuat di media cetak. Karya-karya dari para sastrawan yang sudah mapan akhirnya disandingkan dengan karya-karya dari 
para penulis pemula, yang kualitasnya beberapa masih dipertanyakan, dan mendapat sebutan yang sama sebagai sastra cyber. Di sinilah istilah sastra cyber menjadi bias.

Terlepas dari berbagai hal terkait dengan pro-kontra terhadap munculnya sastra cyber, pemanfaatan media internet sebagai media publikasi karya banyak direspon pengguna internet. Hal ini bisa dilihat dari banyaknya jumlah pengunjung ke berbagai situs yang memuat cerpen.

Selain hal-hal di atas, perlu juga disinggung masalah karakter media. Internet sebagai media publikasi karya sastra memang memiliki sifat yang khas. Kekhasan media itu terletak pada jangkauan penulis dan pembacanya. Di satu sisi jangkauan penulis dan pembaca luas karena internet bisa diakses oleh siapa saja dalam jarak yang tidak terbatas. Di sisi lain, jangkauan penulis dan pembaca terbatas karena hanya orangorang yang mengakses internet yang dapat menjangkau sastra cyber. Selain itu, kemampuan pembaca dan penulis untuk berinteraksi dengan internet juga terbatas karena mengakses internet membutuhkan biaya yang tidak sedikit. Berangkat dari uraian di atas, penelitian ini mencoba menemukan karakteristik cerpen-cerpen cyber dalam berbagai situs yang ada.

Era digital membawa kemungkinan baru dalam perkembangan sastra Indonesia, yaitu munculnya sastra cyber. Internet memberi peluang besar bagi para penulis ini karena tidak perlu dilakukan seleksi terhadap publikasi karya-karya tersebut. Di satu sisi kondisi ini memang menguntungkan, tetapi di sisi lain kualitas karya cyber menjadi dipertanyakan.

Menanggapi hal ini, Medy Loekito yang merupakan presiden Yayasan Multimedia Sastra (melalui Faruk, 2001:220) mengemukakan bantahan sebagai beri- kut. Pertama, internet merupakan saluran yang efektif bagi penyemaian atau terapi terhadap frustasi penyair yang sudah tidak sabar menunggu dalam ketidakpastian penerbitan karyanya di media cetak. Kedua, internet merupakan saluran alternatif bagi penyair menghadapi sikap tidak adil media massa yang mengutamakan nama-nama besar dan bahkan melenyapkan lahan bagi penyair yang belum terkenal. Ketiga, internet merupakan jembatan bagi peradaban multiculture.

Terlepas dari berbagai pro dan kontra terhadap keberadaan sastra cyber ini, antusias pengunjung internet terhadap karya sastra cyber tidak bisa diremehkan. Hal ini menjadi pertimbangan bagi tetap eksisnya sastra cyber ini. Namun, kebiasan istilah sastra cyber juga menjadi ganjalan bagi banyak pihak. Hal ini disebabkan www.cybersastra.net tidak hanya memuat karya-karya yang belum pernah dimuat di media cetak. Karya-karya yang sudah pernah dimuat di media cetak pun ikut terpublikasikan ulang di internet.

Dalam konvensi cerpen, dalam hal ini adalah cerpen cetak, cerpen merupakan cerita yang pendek yang habis dibaca dalam sekali duduk. Panjang cerpen berkisar 1000-1500 kata. Hal ini berbeda dengan karya fiksi yang lain. Novel tidak bisa dibaca dalam sekali duduk karena merupakan cerita yang sangat panjang. Panjang novel lebih dari 45.000 kata. Di antara cerpen dan novel, ada novelet dengan panjang berkisar antara 15.000-45.000 kata.

Panjang cerpen yang hanya 1000-1500 kata membawa konsekuensi dalam penceritaannya. Menurut Sayuti (2000:8-10), ciri-ciri cerpen adalah (1) dibaca sekali duduk, (2) plot diarahkan pada insiden atau peristiwa tunggal, (3) watak tokoh jarang dikembangkan secara penuh, (4) dimensi ruang dan waktu terbatas, (5) adanya compression 
(pemadatan), concentration (pemusatan), dan intensity (pendalaman), dan (6) mencapai keutuhan (unity) secara exclution (eksklusi).

Unsur-unsur intrinsik cerpen terdiri atas cerita, sarana cerita, dan tema. Fakta cerita terdiri atas alur, tokoh, dan latar. Sarana cerita antara lain terdiri atas judul, gaya dan nada, dan sudut pandang. Fakta cerita dibahas dalam uraian uraian berikut.

Alur sering disebut sebagai jiwanya fiksi. Alur merupakan rangkaian peristiwa yang tersusun berdasarkan hubungan kausalitas. Cerpen tersusun dari beberapa peristiwa yang saling berhubungan. Hal ini tampak dalam struktur alur, yang menurut Sayuti (2000:32) dapat dibagi dalam beberapa bagian yaitu awal (eksposisi, instabilitas, dan konflik), tengah (klimaks dan komplikasi), dan akhir (denoument/penyelesaian). Selain itu, pengembangan alur dalam cerita fiksi, menurut Kenny (melalui Nurgiyantoro, 1998:130), harus mengandung kaidah-kaidah alur, yaitu kemasukakalan (plausabilitas), kejutan (surprise), suspense, dan keutuhan (unity).

Tokoh adalah para pelaku dalam cerita fiksi. Menurut Sayuti (), sebagian besar pembaca mengharapkan adanya tokoh-tokoh fiksi yang bersifat alamiah (natural), dalam arti bahwa tokoh memiliki derajat kesepertihidupan (likelifeness). Dalam fiksi, tokoh dapat digambarkan dengan berbagai cara, yaitu langsung (telling, analitik) dan tidak langsung (showing, dramatik). Penokohan tidak langsung dapat dilakukan dengan sepuluh cara, yaitu teknik penamaan tokoh (naming), cakapan, penggambaran pikiran tokoh, arus kesadaran (stream of consciousness), pelukisan perasaan tokoh, perbuatan tokoh, sikap tokoh, pandangan seorang atau banyak tokoh terhadap tokoh tertentu, pelukisan fisik, dan pelukisan latar (Sayuti, 2000: 89-93).
Latar merupakan unsur fiksi yang mengacu pada tempat, waktu, dan kondisi sosial cerita itu terjadi. Hal ini sejalan dengan pendapat Sayuti (2000:127) yang mengatakan bahwa unsur latar terdiri dari latar tempat, waktu, dan sosial. Ketiga unsur latar tersebut terbangun secara bersama, tidak terputus, dan saling berhubungan.

Selain unsur intrinsik, karya sastra juga memiliki unsur ektrinsik, di antaranya penulis dan pembaca. Menurut Abrams (melalui Wiyatmi, 2006:18), karya sastra merupakan ekspresi sastrawan/penulis sebagai curahan atau luapan perasaan dan pikiran sastrawan sebagai produk imajinasi sastrawan yang bekerja dengan persepsi-persepsi, pikiran-pikiran, atau perasaan-perasaannya. Karya sastra lahir sebagai hasil penangkapan realitas dan penghayatannya oleh sastrawan. Oleh karena itu, realitas yang sama bisa dipersepsi dan dihayati secara berbeda oleh beberapa sastrawan sehingga lahirnya dalam bentuk karya sastra pun berbeda-beda.

Dalam proses berikutnya, karya sastra yang ditulis sastrawan akan diapresiasi oleh pembaca. Bentuk apresiasi terhadap karya sastra pun berbeda-beda, misalnya dibaca, didiskusikan atau dibedah, diresensi, dan sebagainya. Pembacalah yang akan menilai sebuah karya sastra. Bahkan, pembaca jugalah yang akan memberi makna sebuah karya sastra dalam aktivitas pembacaannya itu.

\section{METODE}

Jenis penelitian ini adalah penelitian kualitatif. Hal ini didasarkan pada data dalam penelitian ini yang berupa teks tulis, yaitu cerpen-cerpen yang diambil dari internet. Pendekatan yang digunakan dalam penelitian ini adalah content analysis.

Sumber data penelitian ini adalah cerpen-cerpen dalam www.kolomkita. 
com dan www.kemudian.com. Cerpen-cerpen yang diteliti dibatasi pada cerpen-cerpen yang dimuat pada bulan April 2008. Situs ini adalah situs yang produktif memuat cerpen. Selain itu, situs ini juga secara spesifik hanya memuat cerpen-cerpen yang belum pernah dimuat di media massa. Selanjutnya, nama situs ini secara bergantian akan menggunakan istilah KolomKita. com dan Kemudian.com.

Data dalam penelitian ini diperoleh melalui teknik pembacaan intensif, pencatatan, dan analisis. Instrumen yang digunakan dalam penelitian ini adalah human instrument. Artinya, bahwa peneliti selaku orang yang berkecimpung dalam dunia akademisi dan memiliki kualifikasi dalam bidang yang diteliti (penulisan) secara sungguhsungguh melakukan penelitian. Instrumen penelitian yang lain adalah kartu data dan cerpen-cerpen dalam KolomKita.com dan Kemudian.com.

Analisis data dilakukan dengan menggunakan teknik deskriptif kualitatif yang mendeskripsikan dan merumuskan data yang berupa cerpen-cerpen di KolomKita.com dan Kemudian.com. Sesuai alur kerja kajian analisis konten yang digunakan dalam penelitian ini, beberapa rangkaian kegiatan dalam tahapan analisis data mencakup: (1) penyajian data, (2) kategorisasi dan pembandingan, (3) tabulasi, dan (4) inferensi.

Validitas dalam penelitian ini dilakukan melalui validitas isi (konstruk), yaitu berupa analisis isi terkait dengan genre dan teori yang mendasarinya. Selain itu, validitas semantik juga digunakan dengan mengaitkan tulisan dengan interpretasi makna dan konteks yang melingkupnya. Kevalidan data dilakukan dengan membaca dan meng-analisis secara cermat, teliti, dan berulangulang. Data yang valid didasarkan pada kemunculan kembali (reproducibility). Pertimbangan reliabilitas dilakukan melalui teknik intrarater dan interrater. Interrater dalam penelitian ini adalah pembimbing, Prof. Dr. Suminto A. Sayuti, pakar sastra Indonesia Modern

\section{HASIL DAN PEMBAHASAN}

KolomKita.com merupakan wadah berkarya -dalam hal ini menulis- bagi para pengguna internet. Untuk bisa menulis di situs ini, para pengguna harus mendaftar dengan mengisi User ID dan password. Dengan user ID dan password ini, para anggota dapat menulis dan memberi tanggapan terhadap tulisantulisan yang ada di dalamnya. Definisi situs ini dapat dilihat pada link "tanya jawab" berikut, "KolomKita.com adalah tempat semua orang berbagi cerita pada dunia dengan menggunakan bahasa Indonesia sebagai bahasa utama dan bahasa Inggris sebagai bahasa kedua."

Adapun ketentuan menjadi anggota KolomKita.com dapat dilihat pada kutipan berikut.

\section{Ketentuan KolomKita.com}

Dengan menjadi anggota

KolomKita.com (KKC) Anda bersedia untuk:

- menjaga nama baik situs KolomKita. com.

- tidak menulis sesuatu yang menyerang SARA maupun mengandung propaganda tertentu.

- tidak membebani anggota lain dengan bentuk apapun juga seperti spamming (baik itu dalam bentuk email maupun komentar) dan lain sebagainya.

- mengirimkan tulisan yang merupakan hasil karya diri sendiri dan bukan orang lain.

- setuju dengan segala ketentuan yang berlaku selama menjadi anggota KKC.

KolomKita.com memiliki semboyan “Ceritakan pada Dunia”. Link yang di- 
miliki situs ini adalah "muka", "daftar", "login", "ketentuan", "tanya jawab", "kontak", dan "sitemap". KolomKita.com memiliki pengelompokan dan klasifikasi tulisan yang lebih rapi. Hal ini memudahkan pembaca untuk menemukan tulisan sesuai kategorinya. KolomKita.com memiliki aturan dalam memuat tulisan yang masuk.

Ta : Berapa lama kira-kira tulisan saya dapat disetujui untuk dimuat?

Wa : Setelah diterima oleh redaksi, tulisan Anda akan dimuat paling cepat 24 jam setelahnya. Pada kondisi tertentu di mana tulisan yang masuk berjumlah ratusan maka akan butuh waktu beberapa hari sampai minggu untuk menyeleksinya.

Ta : Apakah akan ada pemberitahuan jika tulisan ditolak oleh redaksi?

Wa : Tidak.

Ta : Apakah tulisan yang diterima redaksi pasti dimuat di KKC?

Wa : Tulisan yang diterima redaksi pasti akan dimuat selama tidak melanggar ketentuan KKC. Redaksi berhak untuk tidak memuat / menghapus tulisan tanpa memberitahukan alasannya.

Informasi ini dilengkapi dengan "Jenis Tulisan yang Tidak akan Dimuat" yang terdapat pada halaman "Petunjuk Penulisan"..

\section{Jenis tulisan yang tidak akan dimuat:}

1. Tulisan yang sulit untuk diedit seperti:menggunakanukuran fontyang tidak standard (terlalu besar / kecil), penggunaan huruf besar, huruf tebal, huruf miring yang berlebihan, dan lain sebagainya. Anda dianjurkan untuk melihat format tulisan yang telah dimuat di situs ini sebagai panduan dalam menulis.

2. Tulisan yang banyak mengandung kesalahan tata bahasa dan kesalahan ketik. Contoh kesalahan tata bahasa yang banyak ditemukan oleh redaksi:di buang yang seharusnya: dibuang (awalan + kata kerja / suatu kata yang membentuk kata kerja seharusnya disambung) disebelah sana yang seharusnya: di sebelah sana (awalan + kata keterangan seharusnya dipi-sah). menaklukan yang seharusnya: menaklukkan (akhiran -kan yang fungsinya membentuk kata kerja seringkali diganti menjadi -an yang fungsinya membentuk kata benda). Kami akan berusaha semaksimal mungkin untuk memperbaiki kesalahan yang tidak disengaja, akan tetapi karena keterbatasan waktu dan tenaga kami, tidak mungkin kami dapat memeriksa setiap kata dan kalimat dari naskah-naskah yang sampai di meja redaksi. Jika kami menemukan satu naskah dengan kesalahan yang berulang-ulang, maka kami akan berhenti menyunting naskah tersebut dan tidak akan memuatnya.

3. Kolomkita adalah situs sastra yang netral dan diperuntukkan bagi setiap orang tanpa memandang golongan, agama dan lain sebagainya. Oleh karenanya, untuk menjaga netralitas Kolomkita maka hasil karya yang bernuansa fanatisme agama dan yang memprovokasi issue SARA tidak dapat kami muat. Akan tetapi hal ini bukan berarti tulisan yang mengandung unsur keagamaan tidak dapat dimuat, asal tidak terlalu berlebihan tulisan yang bernuansa keagamaan \& spiritualitas akan kami muat. 
Sementara itu, Kemudian.com adalah wadah berkarya dan mengapresiasi karya bagi para pengguna internet. Kemudian.com memiliki semboyan "menulis, membaca, mengapresiasi" dan memiliki 5 link, yaitu "cerita", "puisi", "forum", "kitab", dan "kolaborasi". Informasi lebih lengkap dapat dilihat pada kutipan halaman depan situs berikut ini.

\section{Kemudian.com}

Kemudian.com adalah wadah berkhayal, bukan bercerita tentang kehidupan sebenarnya. Disini cerita tentang hal yang mustahil adalah wajar.

Penulis dapat menampilkan cerita yang telah rampung atau cerita yang baru tercetus idenya, settingnya, tokohnya atau bahkan endingnya. Setiap anggota boleh menambahkan bagian lain dari cerita, kemudian bersama-sama kita membentuk cerita itu menjadi suatu cerita yang utuh.

Karena semua keberhasilan berawal dari mimpi, mengapa kita tak bermimpi bersama-sama?

\section{Karakteristik Situs Cerpen Cyber}

Setiap situs yang memuat cerpencerpen cyber memiliki karakteristik yang berbeda-beda. Hal ini sangat ditentukan oleh pengelolanya, baik visi maupun personalnya. Berbeda dengan media cetak yang dikendalikan oleh para redaktur dan jumlah oplah, situs di internet lebih sulit dikendalikan. Biasanya situs hanya ditangani oleh satu atau dua orang sebagai admin. Tugas mereka di antaranya adalah menerima naskah, mengeluarkan naskah ke setiap kategori, mendelete naskah-naskah lama, menjawab pertanyaan para anggota, membenahi jika ada sistem yang eror atau rusak, dan menge- luarkan pengumuman terkait dengan berbagai hal di dalam situs tersebut.

Membandingkan situs Kemudian. com dan KolomKita.com, pertama kali dapat dilihat visi masing-masing situs ini. Kemudian.com memiliki visi "menulis, membaca, mengapresiasi", sedangkan KolomKita.com memiliki visi "ceritakan pada dunia". Visi ini menggambarkan aktivitas para anggota di dalam situs tersebut.

Visi "menulis, membaca, mengapresiasi" bagi Kemudian.com dipertegas oleh definisi situs ini, "Kemudian.com adalah wadah berkhayal, bukan bercerita tentang kehidupan sebenarnya. Di sini cerita tentang hal yang mustahil adalah wajar." Sementara itu, visi KolomKita. com dipertegas dengan definisi situs ini, "KolomKita.com adalah tempat semua orang berbagi cerita pada dunia dengan menggunakan bahasa Indonesia sebagai bahasa utama dan bahasa Inggris sebagai bahasa kedua." Artinya, kedua situs ini merupakan wadah yang sama untuk menulis.

Terkait dengan pengelolaan tulisan, Kemudian.com tampak lebih longgar dibanding KolomKita.com. Kemudian. com tidak mensyaratkan kiriman tulisan itu jadi atau selesai. Mereka memberi kelonggaran untuk menulis semampu mereka, walaupun baru cetusan ide, setting, atau tokoh. Situs ini juga tidak mensyaratkan masalah editing bahasa dalam tulisan-tulisan para anggotanya.

Sementara itu, KolomKita.com terkesan lebih selektif dengan upayanya mengeluarkan "Ketentuan KolomKita. com", "Panduan Menulis", dan "Jenis Tulisan yang Tidak Dimuat". Meskipun aturan-aturan tersebut masih terbatas pada masalah penulisannya, yaitu masalah bahasa, tetapi ini langkah maju bagi KolomKita.com untuk menjaga kualitas tulisannya. 
Terlepas dari keduanya memiliki kelonggaran dan aturan dalam memuat tulisan-tulisan yang masuk, tetapi kedua situs ini menerapkan aturan bahwa semua tulisan yang masuk akan dimuat. Dengan kata lain, pengelola situs tidak melakukan proses seleksi. Hal ini membawa konsekuensi pada kematangan tulisan. Lebih lanjut, hal ini akan diba- has pada karakteristik fakta cerita pada bagian berikutnya.

\section{Karakteristik Fakta Cerita Cerpen Cyber}

Berikut ini adalah tabel perbandingan fakta cerita cerpen KolomKita. com dan Kemudian.com.

\section{Tabel 1 Perbandingan Fakta Cerita Cerpen KolomKita.com dan Kemudian.com}

\begin{tabular}{|c|c|c|c|}
\hline \multirow[t]{2}{*}{ No. } & \multirow[t]{2}{*}{ Unsur } & \multicolumn{2}{|c|}{$\%$} \\
\hline & & KolomKita.com & Kemudian.com \\
\hline 1 & Tema cinta dan pergaulan remaja & 48 & 78 \\
\hline 2 & Ada kesalahan & 29 & 61 \\
\hline 3 & $\begin{array}{l}\text { Cerita fokus (tidak melebar tanpa } \\
\text { arah) }\end{array}$ & 72 & 83 \\
\hline 4 & Cerita selesai & 90 & 39 \\
\hline 5 & Bangunan peristiwa padu & 72 & 89 \\
\hline 6 & Struktur cerita proporsional & 72 & 55 \\
\hline 7 & $\begin{array}{l}\text { Pembukaan cerita tidak bertele- } \\
\text { tele }\end{array}$ & 67 & 67 \\
\hline 8 & Konflik tergarap & 86 & 28 \\
\hline 9 & klimaks terbangun & 67 & 28 \\
\hline 10 & $\begin{array}{l}\text { Ending menarik/tidak mudah } \\
\text { ditebak }\end{array}$ & 52 & 44 \\
\hline 11 & Tokoh hidup/memiliki karakter & 62 & 78 \\
\hline 12 & $\begin{array}{l}\text { Tokoh memiliki kontribusi dalam } \\
\text { cerita }\end{array}$ & 52 & 61 \\
\hline 13 & $\begin{array}{l}\text { Tokoh digambarkan dengan } \\
\text { menarik }\end{array}$ & 76 & 50 \\
\hline 14 & Tokoh utama remaja & 48 & 78 \\
\hline 15 & Latar terolah dengan baik & 72 & 72 \\
\hline
\end{tabular}

Karakteristik cerpen, dalam hal ini fakta cerita, sangat ditentukan oleh karakteristik situs yang menaunginya. Pada bagian lain bab ini telah dibahas karakteristik situs cerpen cyber. Hal ini bisa dianalogkan dengan media cetak, baik koran atau majalah, yang memiliki rubrik cerpen di dalamnya. Karakteristik cerpen di dalam media cetak sangat di- tentukan oleh karakteristik medianya. Pertama, cerpen di media dibatasi oleh jumlah halaman (biasanya 6-8 halaman, spasi 2). Hal ini terjadi karena media cetak memiliki kepentingan terhadap setiap ruangnya, terutama kepentingan bisnis. Hal ini tentu berbeda dengan cerpen dalam buku yang bisa ditulis dengan sangat panjang, seperti cerpen "Seribu 
Kunang-Kunang di Manhattan" karya Umar Kayam dan "Kritikus Adinan" karya Budi Darma. Kedua, sebagaimana ditulis oleh Mahayana (1999:481), sastra di media cetak dibatasi oleh kebijaksanaan redaksi, kesesuaian misi media, kepentingan masyarakat pembaca, pertimbangan komersial, dan kesesuaian citra media.
Dalam konvensi cerpen cetak, panjang cerpen berkisar 1000-1500 kata. Hal ini berbeda dengan karya fiksi yang lain. Jika diklasifikasikan menurut konvensi sastra cetak, hasil perbandingan tersebut dapat diturunkan lagi dalam tabel berikut.

Tabel 2 Perbandingan Jumlah Cerpen Berdasar Jumlah Kata

\begin{tabular}{ccccccc}
\hline \multirow{2}{*}{ JUMLAH KATA } & \multicolumn{2}{c}{ KolomKita.com } & \multicolumn{2}{c}{ Kemudian.com } & \multicolumn{2}{c}{ TOTAL } \\
\cline { 2 - 7 } & Jumlah & $\%$ & Jumlah & $\%$ & Jumlah & \% \\
\hline$<1000$ kata & 6 & 29 & 10 & 56 & 16 & 41 \\
1000-1500 kata & 7 & 33 & 4 & 22 & 11 & 28 \\
$>1500$ kata & 8 & 38 & 4 & 22 & 12 & 31 \\
& 21 & 100 & 18 & 100 & 39 & 100 \\
\hline
\end{tabular}

Dari data didapatkan bahwa kebanyakan cerpen cyber memiliki jumlah kata < 1000 kata. Hal ini memiliki korelasi dengan data bahwa hanya 39\% cerpen Kemudian.com tersebut selesai. Selesai di sini dalam arti bahwa alur cerpen tersebut memiliki awal, tengah, dan akhir secara proporsional, selain juga memiliki konflik dan klimaks yang terbangun bagus. Banyak cerpen di Kemudian.com terbangun sebagai curahan hati saja. Kadang-kadang penulis hanya menceritakan satu peritiwa dengan menyebutkan tokoh dan settingnya, tetapi tidak membangun konflik, apalagi klimaks. Dari data didapatkan hanya 28\% cerpen yang menggarap konflik dan membangun klimaks dengan baik. Hal ini merupakan sesuatu yang wajar dan diterima dalam komunitas Kemudian. com. Pihak pengelola sendiri memberi kelonggaran kepada para penulis untuk menampilkan cerita yang tidak selesai.

Sebagai contoh, berikut ini adalah cerpen yang pendek, yang tidak membangun konflik dan klimaks. Cerpen ini dimuat pada 27 April 2008 dengan penulis berinisial Shinichi.

\section{Di Dalam Kelas}

Di suatu kelas...

"Sekarang kita belajar bernyanyi. Siapa yang mau menyanyi di depan kelas?" tanya guru itu riang. "Saya, Bu!" riuh suara generasi bangsa sambil menyahut tak karuan. Ramai. Guru itu tersenyum riang karena murid-muridnya bersemangat sekali mengikuti pelajaran menyanyi.

“Wita! Mau nyanyi di depan kelas?" tanya guru itu.

"Mau, Bu!" sahut Wita dengan nyaring.

Wita, gadis mungil dengan pita merah jambu di kedua kepang rambutnya berjalan pelan menuju depan kelas. Ia berbalik dan mulai menarik nafas sambil menghadap teman-temannya. Kedua tangannya dilipat ke belakang dan tubuh kecilnya bergoyang.

"Kumencintaimu lebih dari apapun. Meskipun engkau hanya kekasih gelapku..." 
Selain cerpen yang pendek, kadang-kadang cerpen di dalam internet juga merupakan perbaikan atau kelanjutan dari cerpen yang ditulis sebelumnya, dengan kalimat awal di cerpen, "Sedikit sambungan dari cerpen "Di Hari Ulang Tahun $\mathrm{Na}^{\prime}$. Hal ini menandakan bahwa cerpen yang dimuat di dalam internet bukanlah cerpen yang matang. Artinya, cerpen itu belum selesai dan bisa diselesaikan kapan pun mereka mendapat ide yang baru.

Hal ini juga diperkuat oleh munculnya beberapa penulis yang memulai tulisannya dengan kata-kata pesan, seperti "... silakan diceramahin, dikritik abis-abisan, dipuji juga boleh ding" pada cerpen "Di Ruang Ujian", atau “... nyobain teenlit ah ..., silakan dikritik abis-abisan ..." pada cerpen "Rom dan Perasaanku". Jika cerpen itu mendapat masukan dari pembaca yang lain, cerpen itu dapat diperbaiki dan dimuat lagi.

Sedikit berbeda dengan cerpencerpen Kemudian.com, cerpen-cerpen dalam KolomKita.com tampak lebih matang. Dari data didapatkan ada $90 \%$ cerpen selesai ditulis, $86 \%$ konflik tergarap, dan $67 \%$ klimaks terbangun, meskipun beberapa cerita tampak "kedodoran" dalam pembukaan atau awal cerita, juga dalam penyusunan ending cerita.

Kondisi ini bisa jadi disebabkan oleh faktor pengelola situs. KolomKita. com masih melakukan seleksi, meskipun tidak ketat. Sementara itu, Kemudian.com tidak melakukan apa pun. Semua naskah yang masuk langsung bisa dimuat, apalagi pihak pengelola memberi kelonggaran untuk memuat tulisan yang belum jadi.

Adanya seleksi ini juga tampak pada munculnya kesalahan-kesalahan, baik kesalahan logika atau kesalahan tulisan. Dari data 29\% cerpen KolomKita.com ditemukan adanya kesalahan, sedangkan kesalahan pada cerpen $\mathrm{Ke}$ mudian.com sebanyak $61 \%$. Contoh kes- alahan tulis dapat dilihat pada kutipan berikut.
"Ah... Sinilah!" ia masih menolak. "Ini nah! Hisap aja sesuak hatimu! Tapi, jangan kau minum. Mati kau nanti."
Si penyemir sepatu itu meny- odorkan kotak semirnya. Ia masih memandang-mandang ke jalanan dan rumah makan di seberang.

Cerpen-cerpen dalam KolomKita. com dan Kemudian.com juga memiliki perbedaan dalam menampilkan tematema remaja. Dalam cerpen-cerpen $\mathrm{Ke}$ mudian.com ditemukan $78 \%$ bertemakan remaja (cinta dan pergaulannya). Beberapa cerpen ditemukan memiliki ciriciri teenlit. Sementara itu, hanya $48 \%$ cerpen KolomKita.com yang bertemakan remaja. Cerpen KolomKita.com lebih banyak mengungkapkan dunia orang dewasa (misalnya rumah tangga, konflik batn, dan sebagainya), selain juga konflik sosial.

Hal ini berpengaruh terhadap unsur tokoh dan latar dalam cerpen-cerpen ini. Tokoh-tokoh dalam Kemudian.com lebih banyak dari kalangan remaja, dengan persoalan remaja (misalnya pacaran, upaya diet yang gagal, dan sebagainya) dan latar dunia remaja (misalnya sekolah, salon kecantikan, dan sebagainya). Bahasa yang dipakai dalam cerpen pun banyak menggunakan bahasa gaul. Berikut ini adalah penggalan cerpen "Rom dan Perasaanku".

"Maksudmu apa siy ngajak aku kesini? Kalo aku tahu, bakal denger kau nangis lagi, lebih baik aku nolak!" kataku kesal setelah 1 jam bertarung bersama isak tangis Rom. Ia sudah menangis begitu aku tiba di taman kota. Padahal, aku ada janji ke Mall bersama teman-temanku. Shopping. 
“Aku sedih, Rey! Ternyata Mira cuman mempermainkanku! Huuu..." Duh! Ni anak kok cemen amat? Aku yang cewek aja ga sampe segitunya! "Udahan dong nangisnya, Rom! Ga malu samaku? Aku cewek loh!" kataku sewot.

Sementara itu, cerpen-cerpen dalam KolomKita.com lebih banyak menampilkan tokoh-tokoh dewasa, dengan persoalan-persoalan orang dewasa (misalnya selingkuh dari perkawinan, persoalan keluarga, memutuskan menikah, dan sebagainya).

\section{Karakteristik Penulis dan Pembaca Cerpen Cyber}

Penulis cerpen-cerpen cyber adalah orang-orang yang tergabung dalam situs tersebut. Dari data didapatkan bahwa penulis cerpen-cerpen cyber sebenarnya tidak terlalu banyak. Penulis Penulis cerpen-cerpen cyber adalah orang-orang yang tergabung dalam situs tersebut. Dari data didapatkan bahwa penulis cerpen-cerpen cyber sebenarnya tidak terlalu banyak. Beberapa nama menulis lebih dari satu cerpen selama satu bulan. Bahkan, dalam Kemudian. com, Shinichi menulis sampai 8 cerpen dari 18 cerpen yang ada.

Pembaca cerpen-cerpen ini pun banyak berasal dari anggota situs. Mereka memberi komentar atau respon pada setiap cerpen yang termuat. Pemberi respon pun hanya orang-orang itu saja. Penulis dan pembaca/pemberi respon dalam situs ini tidak banyak menunjukkan identitasnya. Mereka menggunakan nama inisial. Kalaupun mau ditelusuri, identitas yang muncul hanya sebatas tempat atau kota domisili. Bahkan, kadang-kadang sampai tidak diketahui penulis atau pembaca ini lakilaki atau perempuan.

Terlepas dari kematangan cerpennya, sebagai forum saling mengapre- siasi Kemudian.com tampak lebih hidup dan dinamis dibanding KolomKita.com. Pemberi respon pada Kemudian.com berkisar antara 7-11 dalam sebulan. Akan tetapi, hal ini tidak terjadi dalam KolomKita.com yang berada pada kisaran 0-7 respon.

Besarnya respon untuk cerpen pun bukan selalu karena cerpen itu bagus, tetapi seringkali juga karena penasaran, misalnya pada cerpen "Anorexia Nervosa". Dilihat dari teknik penulisannya, cerpen ini tidak menarik karena panjang sekali tanpa ada konflik yang berarti. Cerpen ini seakan hanya ingin menunjukkan definisi istilah yang rumit itu. Kebanyakan respon diberikan untuk wilayah isi cerpen. Masalah teknik pebulisan jarang dibahas.

Terlepas dari beberapa hal tersebut, tampaknya sastra cyber lebih banyak dimanfaatkan sebagai forum untuk saling membaca, saling menulis, dan saling mengapresiasi. Di dunia inilah mereka membangun komunitas untuk menyalurkan bakat dan minatnya dalam menulis. Hal ini menjadi positif untuk membangun budaya menulis.

\section{SIMPULAN}

Dari penelitian terhadap cerpencerpen di kedua situs ini, ada beberapa hal yang bisa disimpulkan. Pertama, karakteristik situs yang memuat cerpencerpen cyber ditentukan oleh pengelolanya, baik visi maupun personalnya. Situs ini memiliki aturan main meskipun tidak sedetil media cetak. Berbeda dengan media cetak yang dikendalikan oleh para redaktur, situs yang memuat cerpen cyber hanya dikendalikan oleh satu atau dua orang sebagai admin. Tugas admin ini di antaranya adalah menerima naskah, memasukkan naskah ke setiap kategori, menhapus naskah-naskah lama, menjawab pertanyaan para anggota, membenahi jika ada sistem yang eror atau rusak, dan mengeluarkan 
pengumuman terkait dengan berbagai hal di dalam situs tersebut.

Kedua, situs yang memuat cerpen cyber hampir tidak memiliki proses seleksi naskah sehingga cerpen-cerpen yang masuk pasti dimuat. Meskipun begitu, setidaknya KolomKita.com melakukan upaya untuk meminimalkan kesalahan penulisan dengan mengeluarkan ketentuan-ketentuan kebahasaan. Karena itu, kesalahan yang muncul pada cerpen-cerpennya relatif sedikit dibanding cerpen-cerpen Kemudian.com. Karena tidak ada seleksi, cerpen-cerpen cyber memiliki beberapa kelemahan, yaitu pada penyelesaian cerita, penggarapan konflik, dan pencapaian klimaks. Selain itu, penggarapan tokoh dan latar seringkali juga tidak optimal.

Dalam dunia cyber, tulisan bisa bebas keluar masuk. Karena itu, seringkali cerpen yang ada adalah cerpen yang belum selesai dan tidak matang. Banyak ditemukan cerpen-cerpen yang hanya menyuguhkan satu peristiwa atau kejadian, diramu menjadi cerita yang utuh. Cerpen-cerpen itu juga seringkali ditarik kembali untuk diparbaiki oleh penulisnya dan ditayangkan lagi dengan bentuk yang baru.

Selain itu, cerpen cyber tidak mensyaratkan panjang tulisan. Ada cerpen yang sangat pendek (yaitu 106 kata), tetapi ada juga cerpen yang sangat panjang (yaitu 7218 kata). Hal disebabkan kebebasan ruang yang dimiliki dunia maya.
Ketiga, penulis dan pembaca cerpen cyber merupakan suatu komunitas sehingga dijumpai sebuah alur dari mereka, oleh mereka, dan untuk mereka. Mereka menjadi penulis sekaligus pembaca yang intens. Meskipun begitu, cerpen-cerpen ini memiliki jangkauan pembaca yang luas sekali karena dunia maya adalah dunia yang tanpa batas.

\section{DAFTAR PUSTAKA}

Faruk. 2001. Beyond Imagination Sastra Mutakhir dan Ideologi. Yogyakarta: Gama Media

Herfanda, Ahmadun Yosi. 2004. "Puisi Cyber, Genre atau Tong Sampah" dalam Cyber Graffiti Polemik Sastra Cyberpunk (Ed. Saut Situmorang). Yogyakarta: Jendela Mahayana, Maman S. 1999. "Menafikan Sastra Koran" dalam Angkatan 2000 dalam Sastra Indonesia. Jakarta: Gramedia

Nurgiyantoro, Burhan. 1998. Teori Pengkajian Fiksi. Yogyakarta: Gadjah Mada University Press

Sayuti, Suminto A. 2000. Berkenalan dengan Prosa. Yogyakarta: Gama Media

Situmorang, Saut (Ed.). 2004. Cyber GraffitiPolemikSastraCyberpunk. Yogyakarta: Jendela

Wiyatmi. 2006. Pengantar Kajian Sastra. Yogyakarta: Penerbit Pustaka

Zuchdi, Darmiyati. 1993. Panduan Penelitian Analisis Konten. Yogyakarta: Lemlit IKIP Yogyakarta 


\section{Lampiran 1 Cerpen-Cerpen dalam KolomKita.com}

\begin{tabular}{|c|c|c|c|c|}
\hline $\begin{array}{l}\text { KODE } \\
\text { CRPN }\end{array}$ & $\begin{array}{c}\text { JML } \\
\text { KATA }\end{array}$ & PENULIS & PEMBERI RESPON & $\begin{array}{c}\text { JML } \\
\text { RESPON }\end{array}$ \\
\hline $\mathrm{C} 1$ & 437 & dedeawan & - & 0 \\
\hline $\mathrm{C} 2$ & 1005 & Wittz & $\begin{array}{l}\text { Hartanto, Nday, apple, He, cHick } \\
\text { gonnaBE }\end{array}$ & 5 \\
\hline $\mathrm{C} 3$ & 1711 & Erwinarianto & Fauzan Masri. Z & 1 \\
\hline $\mathrm{C} 4$ & 697 & indra permana & Delta, maylan st john, Indra & 3 \\
\hline C5 & 1050 & Erwinarianto & - & 0 \\
\hline C6 & 888 & Elegan & dedeawan, Fauzan Masri. Z & 2 \\
\hline $\mathrm{C} 7$ & 1109 & Fauzan Masri Z. & dedeawan, alonk & 2 \\
\hline $\mathrm{C} 8$ & 1240 & $\begin{array}{l}\text { M. Fakhri Islami } \\
\text { Arif }\end{array}$ & - & 0 \\
\hline C9 & 2237 & arki atsema & Fauzan Masri. Z, & 1 \\
\hline $\mathrm{C} 10$ & 1685 & santi tileSTian & Bentang, agung, abudi, afina ray & 4 \\
\hline $\mathrm{C} 11$ & 1070 & Dedeawan & Pemula eza purwi3 & 3 \\
\hline $\mathrm{C} 12$ & 882 & Wittz & - & 0 \\
\hline $\mathrm{C} 13$ & 1011 & Whipra & - & 0 \\
\hline $\mathrm{C} 14$ & 1704 & Whipra & Pembaca & 1 \\
\hline $\mathrm{C} 15$ & 1292 & didi roten & Maylan Maura didi roten destantia & 4 \\
\hline $\mathrm{C} 16$ & 833 & Fauzan Masri Z. & $\begin{array}{l}\text { Pty, dedeawan, rani el shania, alfin } \\
\text { Renata Astry ali }\end{array}$ & 7 \\
\hline $\mathrm{C} 17$ & 7218 & Black Trooper & andy_thio iZzuR & 2 \\
\hline $\mathrm{C} 18$ & 3547 & Erwinarianto & $o 55 y \wedge o^{\wedge}$ Reika yanto & 3 \\
\hline C19 & 1850 & Erwinarianto & adel $055 y \wedge{ }^{\wedge} o^{\wedge}$ & 2 \\
\hline $\mathrm{C} 20$ & 958 & Asayake & Adel & 1 \\
\hline $\mathrm{C} 21$ & 2457 & dedeawan & asep Pettybilly & 3 \\
\hline
\end{tabular}


Lampiran 2. Cerpen-Cerpen dalam Kemudian.com

\begin{tabular}{|c|c|c|c|c|}
\hline $\begin{array}{l}\text { KODE } \\
\text { CRPN }\end{array}$ & $\begin{array}{c}\text { JML } \\
\text { KATA }\end{array}$ & PENULIS & PEMBERI RESPON & $\begin{array}{c}\text { JML } \\
\text { RESPON }\end{array}$ \\
\hline K1 & 423 & Kenary & $\begin{array}{l}\text { aditia angga, Anu, Antony7th, } \\
\text { trisun123, oph elia, takiyo_an-nabhani, } \\
\text { i-rash, niFa_nFa, kaila, Paijo RX }\end{array}$ & 10 \\
\hline K2 & 1534 & Nanasa & $\begin{array}{l}\text { arbibianglala, } \text { Zhanghe, yosi hsn, Nanasa, } \\
\text { Villam, panah hujan, Tedjo. Rijon, ceritasenja }\end{array}$ & 9 \\
\hline K3 & 578 & Shinichi & $\begin{array}{l}\text { Princessa, dirgita, Shinichi, kecurut- } \\
\text { curutan, m4rc3l, Rijon, sicksense, } \\
\text { my_be, djalie, kenary }\end{array}$ & 10 \\
\hline K4 & 1187 & Shinichi & $\begin{array}{l}\text { whitewings, Zhang he, ANNISA, } \\
\text { Princessa, trisun123, Bamby Cahyadi, } \\
\text { xiah, genky, Sang Pujangga }\end{array}$ & 9 \\
\hline K5 & 1613 & Tedjo & $\begin{array}{l}\text { wehahaha, khrisna pabichara, -riNa-, } \\
\text { Ateng, elbintang, Nanasa, Rijon, Tedjo, } \\
\text { cassle, panah hujan }\end{array}$ & 11 \\
\hline K6 & 654 & Shinichi & $\begin{array}{l}\text { starof hope, naela_potter, Rijon, Super } \\
\text { x, Zhang he, Paijo RX, yosi_hsn, } \\
\text { ANNISA }\end{array}$ & 8 \\
\hline K7 & 1098 & $\begin{array}{l}\text { Serpentwit } \\
\text { ch }\end{array}$ & $\begin{array}{l}\text { whitewings, naela_potter, Rijon, donal, } \\
\text { ThePretender, cassle, serpentwitch, } \\
\text { aditia angga, Zhang he }\end{array}$ & 9 \\
\hline K8 & 2330 & Rijon & 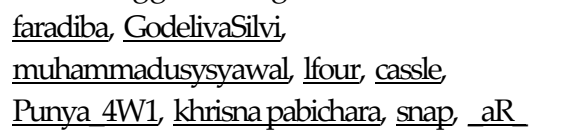 & 9 \\
\hline K9 & 498 & Shinichi & $\begin{array}{l}\text { aditia angga, atok, yunieta, dian } \mathrm{k}, \\
\text { mbahYus, naela_potter, Zhang he, } \\
\text { timbuktu, mel, violet }\end{array}$ & 9 \\
\hline K10 & 2341 & Jalaindra & $\begin{array}{l}\text { RIAK, niFa_nFa, Arra, ga_perlu_tau, } \\
\text { yosi_hsn, elbintang, kiki }\end{array}$ & 7 \\
\hline K11 & 657 & Shinichi & $\begin{array}{l}\text { kes_luph, mel, alifwood, f1f4_91rL, } \\
\text { raka_cobain, genky, naela_potter, } \\
\text { bellabelle, Luna_punk, vivian }\end{array}$ & 10 \\
\hline K12 & 939 & Nanasa & $\begin{array}{l}\text { Paijo RX, senja_saujana, wehahaha, } \\
\text { orchid, RIAK, aancyber, kesabaran, xin- } \\
\text { dhee, Zhang he }\end{array}$ & 9 \\
\hline K13 & 823 & Shinichi & $\begin{array}{l}\text { rouv_azzacky, mel, raka_cobain, snap, } \\
\text { patsy, Villam, atok, dian k, yosi_hsn, } \\
\text { whitewings }\end{array}$ & 10 \\
\hline K14 & 1004 & Patsy & $\begin{array}{l}\text { khrisna pabichara, i-rash, Rijon, } \\
\text { raka_cobain, Bamby Cahyadi, zera, } \\
\text { Shinichi, haikalajadeh, Bintang Timoer }\end{array}$ & 9 \\
\hline K15 & 924 & Frenzy & $\begin{array}{l}\text {-riNa-, bunda ery, my bro, yugi yakuza, } \\
\text { Arra, fortherose, Villam, iris, julian speed, } \\
\underline{\text { Paijo RX }}\end{array}$ & 10 \\
\hline
\end{tabular}




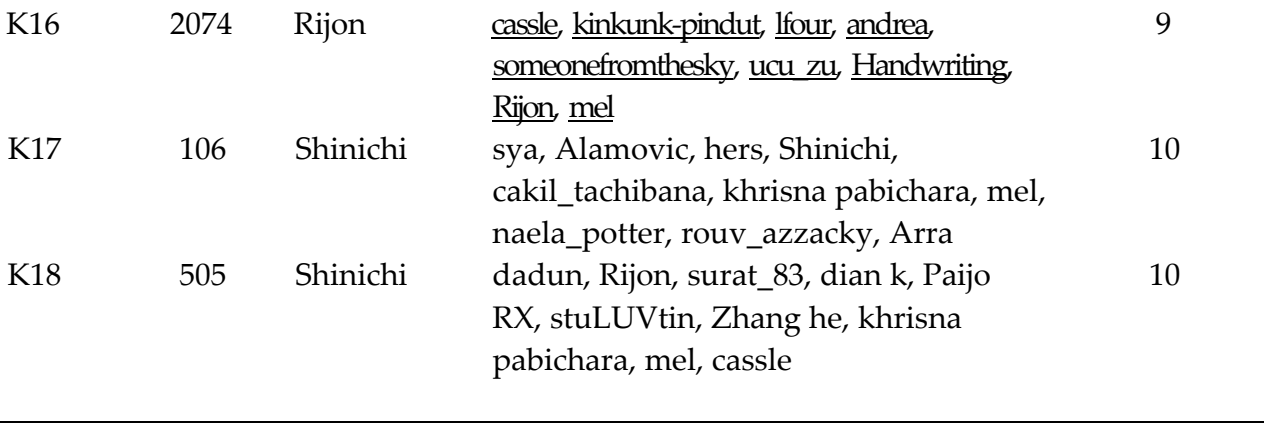

